\title{
MENINGKATKAN HASIL BELAJAR PKn MELALUI PENERAPAN MODEL PEMBELAJARAN KOOPERATIF TIPE NUMBER HEAD TOGETHER (NHT) PADA SISWA KELAS V SDN 1 MIKUASI
}

\author{
Megawati', Sakka Hasan ${ }^{2)}$ \\ 1) SDN 1 Mikuasi, Kolaka Utara, Indonesia \\ ${ }^{2)}$ Jurusan PGSD, Universitas Halu Oleo, Kendari, Indonesia \\ email: megawatii.pji@gmail.com
}

\begin{abstract}
Abstrak: Tujuan dari penelitian ini adalah untuk meningkatkan hasil belajar PKn materi Menjaga Keutuhan NKRI melalui penerapan Model Pembelajaran Kooperatif Tipe NHT melalui penerapan Model Pembelajaran Kooperatif Tipe NHT pada siswa Kelas V SDN 1 Mikuasi Kabupaten Kolaka Utara. Prosedur penelitian yaitu; (a) perencanaan (planning), (b) pelaksanaan tindakan (action), (c) observasi dan evaluasi (observation and evaluation), dan (d) refleksi (reflection). Jenis data yaitu data kualitatif dan data kuantitatif. Data kualitatif diperoleh melalui lembar observasi sedangkan data kualitatif melalui tes hasil belajar. Hasil penelitian yaitu pada siklus I 15 siswa tuntas belajar dengan persentase sebasar $71,4 \%$ dan rata-rata 71,4 sedangkan pada siklus II 20 siswa tuntas belajar dengan persentase sebesar 92,2\% dan rata-rata 77,6. Pada siklus I persentase aktivitas mengajar guru pertemuan pertama adalah $73,3 \%$ dan pertemuan kedua $86,7 \%$ sedangkan pada siklus II persentase aktivitas mengajar guru pertemuan pertama sebesar 93,3\% dan pertemuan kedua sebesar 100\%. Pada siklus I persentase aktivitas belajar siswa pertemuan pertama adalah $73,3 \%$ dan pertemuan kedua $80 \%$ sedangkan pada siklus II pertemuan pertama sebesar 93,3\% dan $100 \%$ pada pertemuan kedua.
\end{abstract}

Kata kunci: model pembelajaran number head together; hasil belajar

\section{IMPROVING THE STUDENT'S LEARNING OUTCOMES THROUGH THE APPLICATION OF COOPERATIVE LEARNING MODELS NUMBER HEAD TOGETHER (NHT) TYPE IN STUDENTS CLASS V SDN 1 MIKUASI}

\begin{abstract}
The aim of the study was to improve the Civics learning outcomes in the matter of Maintaining the Unity of the Republic of Indonesia through the application of the NHT Type Cooperative Learning Model through the application of the NHT Type Cooperative Learning Model for Grade V students of SDN 1 Mikuasi, North Kolaka Regency. Research procedures, namely; (a) planning, (b) action, (c) observation and evaluation, and (d) reflection. Types of data are qualitative data and quantitative data. Qualitative data were obtained through observation sheets, while qualitative data were obtained through learning outcomes tests. The result of the research is that in the first cycle 15 students completed learning with a percentage of $71.4 \%$ and an average of 71.4 , while in the second cycle 20 students completed their studies with a percentage of $92.2 \%$ and an average of 77.6. In the first cycle the percentage of teaching activities for the first meeting was $73.3 \%$ and the second meeting was $86.7 \%$, while in the second cycle the percentage of teaching activities for the first meeting was $93.3 \%$ and the second meeting was $100 \%$. In the first cycle the percentage of student learning activities at the first meeting was $73.3 \%$ and the second meeting was $80 \%$, while in the second cycle the first meeting was $93.3 \%$ and $100 \%$ at the second meeting.
\end{abstract}

Keywords: number head together learning model; learning outcomes; 


\section{Pendahuluan}

Ilmu pengetahuan dan teknologi memiliki peran yang strategis dalam membentuk sumber daya manusia yang berkualitas, sehingga tidak berlebihan bila hal ini sering dijadikan parameter untuk mengukur tingkat kemajuan suatu bangsa. Sehubungan dengan hal itu, pendidikan merupakan salah satu wahana yang dapat memberi kontribusi dalam membangun sumber daya manusia yang berkualitas tinggi dan berpotensi dalam arti yang seluas-luasnya.

Pendidikan Kewarganegaraan sebagai salah satu cabang ilmu pengetahuan memegang peranan penting dalam pengembangan ilmu pengetahuan dan teknologi. PKn sebagai bagian dari pendidikan dipilih sebagai sarana bagi siswa agar mampu berpikir logis, etis dan sistematis, hal ini sesuai dengan fungsi pelajaran PKn yang dirumuskan dalam kurikulum, yaitu sebagai wahana untuk mengembangkan penalaran yang dapat menjelaskan permasalahan dalam kehidupan sehari-hari. Oleh karena itu masalah kualitas pengajaran PKn memerlukan perhatian yang serius dari pihak-pihak yang terkait, khususnya para guru PKn yang mengelola pembelajaran secara langsung didalam kelas.

Soemantri (2007, p.25) mengemukakan bahwa Pendidikan Kewarganegaraan merupakan mata pelajaran sosial yang bertujuan membentuk dan membina warga negara yang baik, yaitu warga negara yang tahu, mau, dan mampu berbuat baik. Untuk mencapai tujuan ini sebagai hasil yang dicapai melalui pembelajaran, memang tidaklah mudah. Guru harus mampu menciptakan kondisi pembelajaran yang kondusif, menggairahkan, serta mampu menjalin ikatan emosi antara dirinya sebagai fasilitator dengan siswa. Menurut Sudjana dan Suwariyah (1991, p.23) ada beberapa kondisi dan persyaratan yang harus diciptakan guru dalam kegiatan pembelajaran. Kondisi dan persyaratan tersebut berkenaan dengan aspekaspek psikologis anak, lingkungan dan suasana belajar, bantuan atau bimbingan belajar dari guru, dan bentuk-bentuk belajar.

Keempat kondisi dan persyaratan di atas harus disiapkan dan diciptakan dengan baik. Guru harus mampu menerapkan model pembelajaran dan keterampilan khusus di samping secara benar memahami karakteristik siswa dan cara belajarnya. Model pembelajaran yang menciptakan kondisi pembelajaran sebagai mana disebutkan di atas harus dipilih dengan tepat.

Salah satu faktor yang sangat mendukung keberhasilan guru dalam mengelola pembelajaran adalah kemampuan guru dalam mengelola pembelajaran salah satu diantaranya kemampuan guru dalam menguasai dan menerapkan model pembelajaran di kelas. Guru dituntut untuk menguasai berbagai macam pembelajaran yang sesuai dengan karakteristik materi dan siswa, sehingga dalam penggunaan model pembelajaran tidak harus sama untuk semua pokok bahasan, sebab dapat saja terjadi bahwa suatu model pembelajaran tertentu cocok untuk satu pokok bahasan tetapi tidak cocok untuk pokok bahasan yang lain (Soemantri, 2007, p. 25)

Salah satu model pembelajaran yang melibatkan peran siswa secara aktif adalah model pembelajaran kooperatif tipe NHT. Model pembelajaran ini merupakan model pembelajaran yang mengutamakan adanya kerjasama antara siswa untuk mencapai tujuan pembelajaran. Tujuan pembelajaran kooperatif adalah untuk membangkitkan interaksi yang efektif diantara kelompok dengan anggotanya melalui diskusi. Dengan model pembelajaran ini siswa dapat mengemukakan pemikirannya, saling bertukar pendapat, saling bekerjasama jika ada teman dalam kelompoknya yang mengalami kesulitan sehingga interaksi dapat terjadi secara efektif sehingga memungkinkan semua anggota kelompok dapat menguasai materi pada tingkat yang relatif sejajar. Menurut Nur dalam Suwastana (2016, p.122) Numbered Head Together pada dasarnya merupakan sebuah varian diskusi kelompok, ciri khasnya adalah guru hanya menunjuk seorang siswa yang mewakili kelompoknya tanpa memberi tahu terlebih dahulu siapa yang akan mewakili kelompoknya itu. Ibrahim mengemukakan tiga tujuan yang hendak 
dicapai dalam pembelajaran kooperatif dengan tipe NHT yaitu : Hasil belajar akademik stuktural, Pengakuan adanya keragaman, dan Pengembangan keterampilan sosial (Kagen dalam Zukira, dkk, 2015, p.5). Supriatna, dkk dalam Mulyana, dkk (2016, p.332) mengemukakan bahwa "Seharusnya dalam suatu pembelajaran ilmu pengetahuan sosial tidak lepas dari belajar untuk menguasai proses ilmiah dalam aspek ilmu sosial untuk menemukan/merumuskan konsep/produk ilmiah yang didasari oleh sikap ilmiah secara interdispliner"

Model pembelajaran PKn yang diajarkan di SD merupakan salah satu materi pembelajaran yang harus menyenangkan oleh guru maupun siswa, dalam pembelajaran PKn yang selama ini dilakukan peserta didik diarahkan pada pengembangan akhlak, moral dan perilaku sebagai tuntatan kurikulum PKn.

Kondisi riil yang ditemukan pada siswa kelas V SD Negeri 1 Mikuasi Kabupaten Kolaka Utara, pembelajaran PKn masih diajarkan dengan menggunakan metode ceramah yang menyebabkan motivasi belajar siswa kurang sehingga hasil belajar PKn siswa rendah. Hasil ulangan semester ganjil tahun 2015/2016 menunjukkan bahwa dari 20 orang siswa kelas V SD Negeri 1 Mikuasi Kabupaten Kolaka Utara, hanya 8 siswa memperoleh nilai $\geq 70$ dan 15 orang siswa memperoleh nilai $<70$. Berdasarkan hal tersebut maka peneliti melakukan penelitian tindakan kelas dengan judul "Meningkatkan Hasil Belajar PKn Materi Menjaga Keutuhan NKRI Melalui Penerapan Model Pembelajaran Kooperatif Tipe Number Head Together (NHT) pada Siswa Kelas V SD Negeri 1 Mikuasi Kabupaten Kolaka Utara”.

Hasil penelitian yang dilakukan oleh Rahmawati (2011) dengan judul Keefektifan Model Pembelajaran Kooperatif Tipe NHT pada Pembelajaran PKn Materi Keputusan Bersama Siswa Kelas V SD Negeri 1 Angkasa Tahun Pelajaran 2010/2011. Kesimpulan dari penelitian ini adalah pembelajaran PKn dengan menggunakan model pembelajaran kooperatif tipe NHT lebih efektif daripada pembelajaran PKn dengan menggunakan metode ekspositori pada materi pokok Keputusan Bersama di kelas V SD Negeri 1 Angkasa tahun pelajaran 2008/2009.

Model Pembelajaran Kooperatif Tipe NHT dirancang secara matang dan dilaksanakan secara tepat diharapkan dapat mendorong siswa lebih dapat meningkatkan persiapan dalam menerima pelajaran. Peningkatan motivasi belajar siswa juga diharapkan membawa dampak positif yaitu peningkatan hasil belajar siswa.

Masalah dalam penelitian adalah apakah hasil belajar PKn materi Menjaga Keutuhan NKRI dapat ditingkatkan melalui penerapan Model Pembelajaran Kooperatif Tipe NHT pada siswa Kelas V SDN 1 Mikuasi Kabupaten Kolaka Utara? Tujuan penelitian adalah untuk meningkatkan hasil belajar PKn materi Menjaga Keutuhan NKRI melalui penerapan Model Pembelajaran Kooperatif Tipe NHT melalui penerapan Model Pembelajaran Kooperatif Tipe NHT pada siswa Kelas V SDN 1 Mikuasi Kabupaten Kolaka Utara. Penelitian ini diharapkan dapat memberikan manfaat bagi guru, siswa, sekolah dan penelitian lainnya.

\section{Metode}

Jenis penelitian ini adalah penelitian tindakan kelas (PTK). Penelitian ini adalah suatu bentuk kajian yang bersifat reflektif oleh pelaku tindakan. Dalam prosedur pelaksanaannya dilakukan dengan proses pengkajian berdaur yang terdiri dari empat tahap yaitu: merencanakan, melakukan tindakan, mengamati, evaluasi dan refleksi. Penelitian ini dilaksanakan pada semester I tahun pelajaran 2016/2017 bertempat di kelas V SD Negeri 1 Mikuasi. Penelitian ini disetting dalam dua siklus, setiap siklus dilaksanakan tindakan pembelajaran dalam dua kali pertemuan. Subjek penelitian ini adalah guru dan siswa kelas V SD Negeri 1 Mikuasi. Peneliti memilih SD Negeri 1 Mikuasi sebagai tempat melakukan Penelitian Tindakan Kelas, karena peneliti telah lama mengajar di sekolah tersebut sehingga 
peneliti dapat merasakan secara langsung permasalahan yang ada pada proses pembelajaran. Jumlah siswa kelas V SD Negeri 1 Mikuasi sebanyak 21 orang, masing-masing terdiri dari 10 orang siswa perempuan dan 11 orang laki-laki. Faktor yang diteliti dalam penelitian ini adalah 1) faktor siswa, 2) Faktor guru dan faktor 3) hasil belajar. Penelitian Tindakan Kelas ini dilaksanakan dalam 2 (dua) siklus. Adapun prosedur penelitian tindakan ini meliputi: (1) Perencanaan, (2) Pelaksanaan Tindakan, (3) Observasi dan Evaluasi, dan (4) Refleksi dalam setiap siklus. Jenis data yaitu data kualitatif dan data kuantitatif. Data kualitatif diperoleh melalui observasi, menggunakan lembar observasi sedangkan data kuantitatif diperoleh melalui tes setiap akhir siklus tindakan

berikut.

Data dalam penelitian ini dianalisis secara deskriptif dengan langkah-langkah sebagai

1. Menentukan ketuntasan belajar

1) Ketuntasan Individu

Ketuntasan individu siswa ditentukan berdasarkan nilai yang diperoleh pada setiap siklus. Siswa dikatakan belajar tutas jika nilai yang diperoleh siswa adalah $\geq 70$ sesuai KKM yang ditetapkan sekolah.

2) Ketuntasan Klasikal

Ketuntasan klasikal ditentukan berdasarkan persentase ketuntasan individu siswa pada setiap siklus pembelajaran dengan rumus sebagai berikut.

$$
\% \text { tuntas }=\frac{\sum f i}{n} \times 100 \%
$$

Dengan:

$$
\begin{aligned}
& \text { n : Jumlah siswa secara keseluruhan } \\
& \sum f i \text { : Jumlah siswa pada kategori ketuntasan belajar (Suparno, 2008, }
\end{aligned}
$$

Ketuntasan klasikal tercapai jika minimal $80 \%$ siswa telah mencapai ketuntasan individual.

2. Menentukan Keberhasilan Aktivitas Mengajar Guru

Untuk menentukan keberhasilan aktivitas mengajar guru dapat dilihat pada keterlaksanaan skenario pembelajaran. Persentase keterlaksanaan skenario pembelajaran dihitung berdasarkan jumlah skor perolehan guru dibagi dengan jumlah skor maksimum dikalikan dengan seratus persen.

$\% K A M G=\frac{J S P G}{J S M G} \times 100 \% \quad($ Usman dan Setiawati, 1993, p.139)

Dengan:

JSPG : Jumlah skor perolehan guru dalam pelaksanaan skenario pembelajaran

JSMG : Jumlah skor maksimum skenario pembelajaran

3. Menentukan Keberhasilan Aktivitas Belajar Siswa

Keberhasilan pembelajaran siswa dihitung berdasarkan skor perolehan siswa kemudian dibagi dengan jumlah skor maksimum dikalikan dengan seratus persen.

$$
\% K A B S=\frac{J S P S}{J S M S} x 100 \% \quad \text { (Usman dan Setiawati, 1993, p.132) }
$$

JSPS : Jumlah skor perolehan siswa dalam mengikuti proses pembelajaran

JSMS : Jumlah skor maksimum proses pembelajaran

Indikator keberhasilan penelitian ini adalah ketuntasan belajar PKn siswa dan keberhasilan proses pembelajaran. Ketuntasan belajar siswa tercapai jika minimal $80 \%$ siswa memperoleh nilai $\geq 70$ sesuai KKM yang ditetapkan sekolah. Proses pembelajaran dikatakan 
berhasil jika persentase keberhasilan aktivitas mengajar guru dan persentase keberhasilan aktivitas belajar siswa mencapai $\geq 80 \%$.

\section{Hasil}

\section{Hasil Belajar Siswa}

Berdasarkan hasil analisis dan pembahasan, menunjukkan bahwa pada siklus I 15 siswa tuntas belajar dengan persentase sebasar $71,4 \%$ dan rata-rata 71,4 sedangkan pada siklus II 20 siswa tuntas belajar dengan persentase sebesar 92,2\% dan rata-rata 77,6.

1. berikut:

Peningkatan ketuntasan belajar siswa pada penelitian ini dapat dilihat pada Gambar

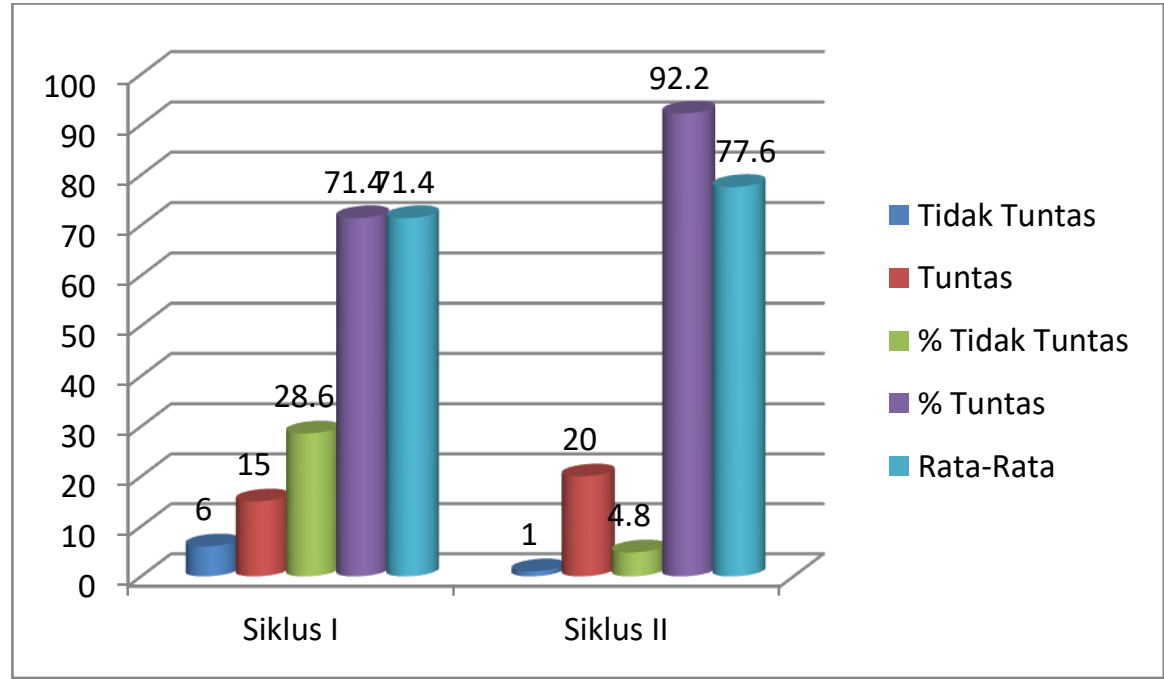

Gambar 1. Grafik Ketuntasan Belajar Siswa Siklus I dan Siklus II

Grafik di atas, menunjukkan bahwa pada siklus I siswa yang mencapai ketuntasan belajar berjumlah 15 orang siswa dengan persentase $71,4 \%$ dan 6 orang siswa lainnya belum mencapai ketuntasan belajar dengan persentase $28,6 \%$ dengan rata-rata nilai sebesar 71,4. Pada siklus II jumlah siswa yang mencapai ketuntasan belajar sebanyak 20 orang siswa dengan persentase sebesar $92,2 \%$ dan 1 orang siswa lainnya belum mencapai ketuntasan belajar dengan persentase 4,8\% dengan rata-rata nilai sebesar 77,6.

\section{Aktivitas Mengajar Guru}

Pada siklus I persentase aktivitas mengajar guru pertemuan pertama adalah 73,3\% dan pertemuan kedua $86,7 \%$ sedangkan pada siklus II persentase aktivitas mengajar guru pertemuan pertama sebesar 93,3\% dan pertemuan kedua sebesar $100 \%$.

\section{Aktivitas Belajar Siswa}

Pada siklus I persentase aktivitas belajar siswa pertemuan pertama adalah 73,3\% dan pertemuan kedua $80 \%$ sedangkan pada siklus II pertemuan pertama sebesar 93,3\% dan 100\% pada pertemuan kedua.

\section{Pembahasan}

\section{Hasil Belajar Siswa}

Hasil belajar siswa ditentukan oleh dua faktor yaitu intern dan ekstren. Faktor intern meliputi pengetahuan yang sudah dimiliki oleh siswa sebelum mengikuti pelajaran berikutnya, keterampilan belajar yang dimiliki oleh siswa, mengerjakan tugas, membaca buku, belajar kelompok, kondisi pribadi siswa yang meliputi kesehatan, kecerdasan, sikap, 
cita-cita. Faktor ekstern meliputi proses belajar mengajar, sarana belajar yang dimiliki, lingkungan belajar, dan kondisi sosial ekonomi keluarga.

Dalam proses pembelajaran, siswa melakukan kerja kelompok atau team. Masingmasing kelompok terdiri atas 4-5 orang siswa, tersebar pada lima kelompok. Ke 5 kelompok tersebut adalah: kelompok A, kelompok B, kelompok C, kelompok D, kelompok E.

Untuk mengukur tingkat keberhasilan perbaikan pembelajaran yang dilakukan, maka guru mengadakan evaluasi pada setiap siklus pembelajaran. Pada evaluasi siklus I, siswa yang memperoleh skor $\geq 70$ sebanyak 15 Siswa (71,4\%), sedangkan siswa yang memperoleh skor $<70$ sebanyak 6 Siswa $(28,6 \%)$ dan skor rata-rata perolehan siswa adalah 70,89. Ketuntasan belajar siswa pada siklus I sudah meningkat yang mencapai $71,4 \%$ akan tetapi belum mencapai indikator keberhasilan penelitian yakni minimal $80 \%$ mencapai ketuntasan belajar. Ketidaktuntasan dari beberapa siswa tersebut diakibatkan kurangnya perhatian siswa pada saat mengikuti pelajaran dan kurang aktif mengerjakan LKS dalam kelompok.

Berdasarkan hasil evaluasi yang dilakukan pada siklus II, siswa yang memperoleh skor $\geq 70$ sebanyak 20 orang $(92,2 \%)$ dengan rata-rata skor perolehan siswa adalah 77,6 . Ini menunjukkan bahwa terjadi peningkatan persentase ketuntasan belajar siswa antara siklus I dan siklus II. Indikator keberhasilan dalam penelitian ini telah tercapai yakni minimal 80\% siswa telah mencapai ketuntasan belajar atau mendapat skor $\geq 70$. Hal ini sesuai dengan pendapat Hill dalam Trianto (2009, p.85) bahwa model NHT dapat meningkatkan prestasi belajar siswa, mampu memperdalam pemahaman siswa, menyenangkan siswa dalam belajar, mengembangkan sikap positif siswa, mengembangkan sikap kepemimpinan siswa, mengembangkan rasa ingin tahu siswa, serta meningkatkan rasa percaya diri siswa.

Pencapaian ketuntasan hasil belajar siswa mengindikasikan bahwa indikator keberhasilan penelitian yang ditetapkan telah tercapai. Tingginya hasil belajar siswa melalui model pembelajaran kooperatif tipe NHT disebabkan karena siswa belajar secara bersama dan saling membantu antara yang siswa yang mampu dengan siswa yang kurang mampu. Dalam pembelajaran kooperatif tipe NHT, siswa bertanya dan mengemukakan pendapatnya dalam proses diskusi kelompok dan diskusi kelas. Sesuatu yang dipelajari apabila siswa aktif mencari, memproses dan mengelola perolahan belajarnya sendiri serta bekerja sama dengan temannya akan lebih lama diingat dibandingkan dengan belajar yang hanya sekedar diperolehnya langsung dari guru dengan melalui ceramah atau informasi semata dari pendidik. Adanya peningkatan aktivitas siswa yang signifikan dari siklus I sampai siklus II karena siswa sudah mampu bersosialisasi dengan baik bahkan sebagian besar siswa sudah dapat mengeluarkan pendapatnya dan menjawab pertanyaan yang diberikan.

\section{Aktivitas mengajar guru}

Penelitian tindakan kelas ini dilaksanakan dalam 2 (dua) siklus. Setiap siklus dilakukan tindakan pembelajaran dalam dua kali pertemuan. Tindakan pembelajaran dilaksanakan sesuai skenario pembelajaran dengan menerapkan model pembelajaran kooperatif tipe NHT. Berdasarkan hasil refleksi terhadap aktivitas guru pada siklus I menunjukkan bahwa penerapan model pembelajaran kooperatif tipe NHT belum sempurna. Pada pembelajaran siklus I pertemuan pertama dan pertemuan kedua, masih terdapat kekurangan-kekurangan yang harus diperbaiki. Hal tersebut terlihat dari hasil observasi yang dilakukan observer terhadap guru (peneliti) yang menunjukkan bahwa skenario pembelajaran belum sepenuhnya terlaksana. Penyampaian materi pembelajaran kurang runtut dan sistematis. Siswa tidak termotivasi untuk mengikuti pelajaran sehingga kurang menumbuhkan keceriaan dan antusias siswa dalam belajar.

Pada pembelajaran siklus II, guru dan siswa telah melakukan kegiatan pembelajaran sesuai yang diharapkan, dimana kekurangan-kekurangan yang terjadi pada siklus I sudah 
diperbaiki. Peneliti sudah mampu mengorganisasikan waktu pembelajaran dengan baik sehingga penggunaan waktu sudah sesuai dengan yang telah ditetapkan. Pernyataan ini sejalan dengan Sanjaya (2008, p.27), untuk merencanakan pembelajaran, alokasi waktu yang diperlukan untuk mempelajari satu materi pelajaran perlu ditentukan. Penentuan alokasi waktu sangat bergantung pada keleluasaan materi serta tingkat kepentingan dengan keadaan dan kebutuhan setempat. Selain itu, guru sudah mampu menumbuhkan keceriaan dan antusias siswa dalam belajar, dan siswa sudah terlihat aktif dalam mengikuti kegiatan pembelajaran.

Hasil observasi pada siklus II menunjukkan bahwa penerapan model pembelajaran kooperatif tipe NHT dalam pembelajaran sudah lebih baik dibandingkan denagan siklus I. Kekurangan yang terjadi pada siklus I sudah dapat diperbaiki.

Langkah perbaikan yang menjadi perhatian guru pada siklus II, yakni: peningkatan kemampuan guru dalam mengelola waktu pada setiap langkah pembelajaran, meningkatkan cara penyampaian materi pembelajaran sehingga materi pelajaran dapat disajikan dengan runtut dan sistematis, peningkatan pemberian motivasi kepada siswa agar siswa dalam mengikuti pembelajaran dengan kondisi yang ceria dan antusias, serta peningkatan pemberian kesempatan pada siswa untuk bertanya agar dalam proses pembelajaran ada umpan balik dari siswa maupun guru. Pada pembelajaran siklus II, guru mampu mengelola waktu dengan baik sehingga proses pembelajaran dapat dilaksanakan secara efektif. Perbaikan yang dilakukan guru pada siklus II, mampu menumbuhkan keceriaan dan antusias siswa dalam belajar.

Pada model pembelajaran kooperatif tipe NHT, pembelajaran menjadi lebih menarik karena guru tidak secara monoton tampil dalam posisi sebagai sumber informasi dan penentu kebijakan dalam pembelajaran, tetapi keterlibatan secara penuh siswa dalam befikir dan proses pencarian pengetahuan akan merangsang daya ingat yang lebih lama dan permanen sebagai siswa.

\section{Aktivitas Belajar Siswa}

Belajar sebagai suatu proses, ditandai dengan adanya perubahan pada diri seseorang. Winkel (1986, p.36) menyatakan bahwa belajar adalah suatu aktivitas mental/psikis, yang berlangsung dalam interaksi aktif dengan lingkungannya, yang menghasilkan perubahanperubahan dalam pengetahuan, pemahaman, keterampilan dan skor sikap. Perubahan itu bersikap secara relatif, konstan dan berbekas.

Aktivitas siswa pada pelaksanaan pembelajaran materi pokok Menjaga keutuhan NKRI dengan model pembelajaran kooperatif tipe NHT, pada siklus I menunjukkan bahwa skor perolehan siswa masih rendah. Siswa belum mempunyai keberanian untuk menjawab pertanyaan yang diajukan guru. Hal ini disebabkan kurangnya rasa kepercayaan diri siswa untuk mengemukakan pendapat. Untuk meningkatkan aktivitas dan hasil belajar, maka hasil refleksi pada siklus I dijadikan dasar peneliti untuk melakukan perbaikan pada siklus II. Melalui perbaikan tersebut, aktivitas siswa pada siklus II sudah mengalami peningkatan terutama keberanian menjawab pertanyaan yang diajukan guru dan siswa sudah dapat mengikuti langkah-langkah pembelajaran kooperatif tipe NHT.

Dengan model pembelajaran kooperatif tipe NHT seperti ini, proses tanya jawab dilakukan dengan cara guru menunjuk siswa secara acak sehingga setiap siswa mau tidak mau harus berpartisipasi aktif, siswa tidak bisa menghindar dari proses pembelajaran, setiap saat siswa bisa dilibatkan dalam proses tanya jawab. Kemungkinan akan terjadi suasana tegang, namun demikian proses interaksi antara guru dan siswa bisa dibiasakan. Untuk mengurangi kondisis tegang tersebut, guru hendaknya membuat serangkaian pertanyaan disertai dengan wajah ramah, suasana menyejukkan, nada lembut. 


\section{Simpulan}

1. Penerapan model pembelajaran kooperatif tipe NHT dapat meningkatkan hasil belajar PKn pada materi menjaga keutuhan NKRI siswa kelas V SD Negeri 1 Mikuasi. Hal ini dapat dilihat pada peningkatan hasil belajar siswa, pada siklus I rata-rata hasil belajar siswa adalah 71,4 dengan persentase ketuntasan hasil belajar sebesar 71,4\% sedangkan pada siklus II rata-rata nilai hasil belajar siswa menjadi 77,6 dengan ketuntasan hasil belajar sebesar $92,2 \%$.

2. Penerapan model pembelajaran kooperatif tipe NHT dapat meningkatkan aktivitas mengajar PKn guru kelas V SD Negeri 1 Mikuasi. Hal ini dapat dilihat dari persentase keberhasilan aktvitas mengahjar guru. Pada siklus I persentase keberhasilan aktivitas mengajar guru pertemuan pertama adalah $73,3 \%$ dan pertemuan kedua $86,7 \%$ dengan ratarata persentase keberhasilan $80 \%$. Pada siklus II persentase keberhasilan aktivitas mengajar guru pertemuan pertama meningkat menjadi $93,3 \%$ dan pertemuan kedua $100 \%$ dengan rata-rata persentase keberhasilan $96,7 \%$.

3. Penerapan model pembelajaran kooperatif tipe NHT dapat meningkatkan aktivitas belajar PKn siswa kelas V SD Negeri 1 Mikuasi. Hal Ini dapat dilihat dari peningkatan persentase keberhasilan aktivitas belajar siswa. Persentase keberhasilan aktivitas belajar siswa siklus I pertemuan pertama adalah $73,3 \%$ dan pertemuan kedua $80 \%$ dengan rata-rata persentase keberhasilan $76,7 \%$ meningkat menjadi $93,3 \%$ pada pertemuan pertama dan $100 \%$ pada pertemuan kedua dengan rata persentase keberhasilan $96,7 \%$ pada siklus II.

\section{Referensi}

Mulyana, M.A., Nurdinah Hanifah, \& Jayadinata, A.K. (2016). Penerapan Model Kooperatif Tipe Numbered Heads Together (NHT) Untuk Meningkatkan Hasil Belajar Siswa Pada Materi Kenampakan Alam Dan Sosial Budaya. Jurnal Pena Ilmiah: Vol. 1, No. 1, 331-340. https://ejournal.upi.edu/index.php/penailmiah/article/download/3039/pdf

Rahmawati. (2011). Pengaruh Persepsi Siswa Tentang Keterapilan Mengajar Guru Dan Motivasi Belajar Siswa Terhadap Hasil Belajar Siswa Pada Mata Pelajaran Akuntansi Kelas XI IPS SMAN 18. Skripsi. Bandung: Universitas Pendidikan Indonesia

Sanjaya, Wina. (2008). Perencanaan dan Desain Sistem Pembelajaran. Jakarta: Kencana Prenada Media Group.

Somantri, T. S. (2007). Psikologi Anak Luar Biasa. Bandung: PT. Refika.Aditama.

Sudjana. (2000). Dasar-Dasar Proses belajar Mengajar. Bandung: PT. Sinar Baru Algesindo.

Sudjana dan Suwariyah. (1991). Model-Model Mengajar CBSA. Bandung: Sinar Baru

Suparno. (2008). Keterampilan Dasar Menulis. Jakarta: Universitas Terbuka.

Suwastana, IW. (2016). Penerapan Pembelajaran Melalui Model Kooperatif Numbered Heads Together Siswa Kelas V SDN No 1 Tonggolobibi Untuk Meningkatkan Prestasi Belajar PKn. Jurnal Kreatif Tadulako Online Vol. 4 No. 1. http://jurnal.untad.ac.id/jurnal/index.php/JKTO/article/download/3281/2324 
Trianto. (2009). Mendesain Model Pembelajaran Inovatif-Progresif. Jakarta: Kencana Prenada Media Group.

Usman, Uzer \& Lilis Setiawati. (1993). Upaya Optimalisasi Kegiatan. Belajar Mengajar. Bandung: Remaja Rosdakarya.

Winkel, W.S. (1991). Psikologi Pengajaran. Jakarta: Gramedia Widiasarana Indonesia.

Zukira, Harun, A.H.\&Jamaludin. (2015). Meningkatkan Hasil Belajar Siswa Kelas III Sekolah Dasar Alkhairaat Towera Melalui Model Pembelajaran Kooperatif Tipe Number Head Together (NHT) Pada Mata Pelajaran PKn. Jurnal Kreatif Tadulako $\begin{array}{llllll}\text { Online } & \text { Vol. } & 3 & \text { No. } & 4, & 1-12 .\end{array}$ http://jurnal.untad.ac.id/jurnal/index.php/JKTO/article/download/3062/2135 